\title{
Manufactured Housing: A Misunderstood Real Estate Market
}

Eric J. Newman, (Email: ernewman@csusb.edu), California State University, San Bernardino

Patrick Fleming, President, Fleming Enterprises

\begin{abstract}
Manufactured Housing started as mobile homes for traveling workers and their families. The mobile homes provided the ability for work crews and their families to easily move from one job site to the next. Today many of the manufactured homes are luxurious homes on permanent foundations that can withstand nature's elements equally or better than stick built homes. The market for manufactured homes will continue to grow as the need for affordable housing continues to grow and the perception continues to improve. Manufactured homes were previously sold by manufactured home dealers. Today real estate agents and investors are moving into the manufactured housing market. Warren Buffet's Berkshire Hathaway Investment Company has recently invested billions in the manufactured housing market. Buffet's presence in the manufactured housing industry changes the perception. This paper looks at some of the benefits and misunderstandings of utilizing manufactured homes in real estate investments.
\end{abstract}

\section{INTRODUCTION}

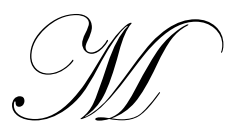

anufactured housing has been misunderstood for many years since originating from coaches and "mobile homes". They have been left with negative perceptions that have been hard to change. The word "mobile home" brings images of a rusty tin trailer surrounded by weeds and trash being greeted by an unemployed toothless gentleman and his five children.

Unfortunately that is the image the media loves to portray during every disaster or media shock attack. The manufactured homes today rival stick built homes and are hard to tell apart. In fact when it comes to withstanding nature's elements, manufactured homes match or exceed a stick built home.

The quality and affordability of manufactured homes have interested real estate investors including Warren Buffet's Berkshire Hathaway Investment Company, which has invested billions of dollars into a market that looks to have a very promising future. The perception of manufactured homes is starting to change with the entrance of more real estate investors and financers. Helping put more families in manufactured homes on permanent foundations and excellent locations is the goal of many new real estate investors.

\section{MANUFACTURED HOMES}

Manufactured homes are built in a controlled indoor factory environment which limits delays due to weather and vandalism. They are built under strict HUD guidelines that have been in effect since June 15, 1976. The homes are built in sections on permanent chassis that are designed to be used with or without a permanent foundation (Koestner 2005). One section would be a single wide, two sections a double wide, and additional sections can be added depending on the size of the property and desired home square footage. Homes are generally located in a Manufactured Home Park, which is very common for the old mobile homes (prior to 1976) or on private land. There are over 2,500 manufactured home communities just in Southern California and still growing (McClintock 2003). According to the U.S. Census Bureau, $70 \%$ of new manufactured home buyers place their homes on private land with a foundation. There are more financing opportunities when the home is placed on a permanent foundation including standard mortgage, FHA, and VA loans (Long 2004, Graves 2004). 
There are a number of different types of homes that come from a factory. It is hard to find a home today that doesn't have a number of pre-built components like trusses or framed walls. A true manufactured home has to be designed to meet federal standards that regulate the housing design, construction, quality, strength, durability, energy efficiency, fire resistance, and transportability (MHI 2005). A manufactured home can easily withstand 60-75 mile an hour winds as it travels down the highway to the destination site.

\section{HISTORY}

The original manufactured home was a "trailer coach" which was used for vacationing. During WWII factory workers had to travel great distances from home. They started using the "trailer coaches"" as housing for the new factory workers. After the war the housing demand was in short supply especially affordable housing. The industry built larger coaches with all the needed appliances which could house a family. These homes could be moved from one location to another providing flexibility for the family. The homes became known as mobile homes.

The HUD code of 1976 provided regulations for mobile homes that defined them as a building rather than a vehicle. The Housing Act of 1980 officially changed the terminology of what a manufactured or factory built home was. The act replaced the terminology of "mobile homes" to only homes built prior to 1976 and manufactured homes to all homes built after 1976 in all federal laws and literature. The manufactured homes of today are built of excellent quality with little resemblance to the old coaches. It is often hard to tell the difference between a manufactured home and a non-manufactured home. Laws in California and other states allow manufactured homes to be installed on conventional single family home sites within any neighborhood, as long as they meet the basic architectural standards and CC\&R's. Covenants, conditions, and restrictions (CC\&Rs) adopted after January 1, 1988 in California can't restrict manufactured homes as long as they meet the basic standards of the on-site homes. The manufactured homes of today are available with cherry-wood cabinets, crown molding, and granite countertops. In Northern California there is a manufactured home project that provides the land with an upscale manufactured home starting in the upper $\$ 800,000$ with some manufactured homes expected to top $\$ 1$ million (Skipitares 2005). In Malibu, California it is common for residents at Paradise Cove to spend a half million dollars on a manufactured home then later replacing it with a million dollar manufactured home (Navarro 2005).

\section{BENEFITS AND DRAWBACKS}

One benefit of manufactured housing is the lack of subcontractors because other than your onsite work the home is warranted and built by one manufacturer. The home quality is consistent with square corners, straight walls, and has gone through factory and road testing. One of the major drawbacks of manufactured housing is the negative perception of consumers which are continually reinforced by the media and visible old mobile homes (Hullibarger). At a recent real estate seminar a speaker deliberately misled the audience when it came to manufactured homes. He recommended that everyone should stay away from "mobile homes" because they just get taken out by every storm. He helped the audience draw on their perception of mobile homes from sensationalized pictures seen on the news stations during storm warnings. Today's manufactured homes are anchored and have been shown to withstand tornados better than stick built homes (Handley 2005). In fact, insurance research has shown that site-built homes are twice as likely to experience fires as manufactured homes (Taylor 2004). The speaker was using the negative perception of mobile homes to make his stick built homes more appealing as a better alternative.

The interest in manufactured housing is growing in a different market than the past. Negative perception has been a major problem that manufactured housing will have to deal with for many years. An interesting side note is how mobile homes have such a bad name yet they are still being occupied over 30 years later. It has been hard to get rid of the trailer trash used car salesman perception that has followed the industry for years and justifiably so. This perception is justified due to the way the manufactured homes were sold for many years. Much like a used car salesman manufactured home sales personnel pushed the homes to everyone whether they could afford it or not. While pushing the homes onto the consumers their reputation was completely tarnished because the homes were pushed onto consumers who could not afford the home payments. Many of the homes were repossessed and soon manufactured home dealers looked like used car dealers with hundreds of used manufactured homes lined up on their lots. That also provided the beginning of the downturn in the number of manufactured homes purchased. The sales 
personnel oversold, the finance people provided unqualified loans, and the factories in return over produced. Over the last 10 years production of manufactured homes has decreased by $61.5 \%$ while the average cost of a manufactured home has increased by $56.2 \%$ (U.S. Census). There could be a correlation between the price and the decrease in home production. The one state that has continued to grow throughout the manufactured home downturn is California. California has a $194.4 \%$ increase in home production with a $67.8 \%$ increase in average manufactured home price over the last 10 years. The hardest hit state is Texas who has decreased in manufactured home production by $66.9 \%$. Between the bad financing and the S \& L scandal, Texas went from producing 45,277 manufactured homes a year to 10,924 ten years later (U.S. Census 2004).

Today the majority of manufactured homes are not financed by the factories or chattel mortgages like they were 10 years ago. Today most loans are processed by many different mortgage companies that qualify the candidates better than they did previously during the boom which brought the crash (Grissim 2003). Financing is a very important part of the manufactured home process. Funds are needed for the land purchase, permits, on site work, the manufactured home down payment, the final manufactured home payment, transportation and setup costs. The manufactured home process provides the opportunity to start with bare land and within months have a completed home. With proper financing the manufactured home investment process can provide affordable homes in a short time frame.

\section{TIME FRAME}

Depending on the land, manufacturer, and wholesaler the manufactured home process can take anywhere from 60-180 days from the time of the order until it can be occupied (LePage 2004). The short setup time of the manufactured home provides the opportunity for a quick return on investment providing the opportunity to continue the buying and selling process. The normal home purchaser can not come up with the cash to purchase bare land, building permits, on-site work, manufactured home purchase (from order to occupancy), and all other expenses associated with the building and setup of the home. A manufactured home can cost $\$ 40$ less per square foot than a neighboring stick built home and be of better quality (U.S. Census 2004). That difference can be very profitable for the investor because when the home is completed on a permanent foundation with a garage it will be valued to comparable real estate in the area. HUD considers the manufactured home real estate and the home quality will meet or surpass most homes in the area. In some markets the appreciation rate has been slightly slower than a traditional home but in states like California and Texas manufactured homes have shown to appreciate the same as a traditional home (Harris 2004).

\section{WARRANTIES}

Manufactured homes can alleviate many of the home buying headaches and save 20 plus percent over the cost of a comparable conventional home (McClintock 2003). They come with a standard one year warranty on basic plumbing, light fixture, appliances, and cosmetic defects. A five year warranty on internal and external walls, electrical systems, plumbing systems, and the chassis frame (Burnside 2002). The quality control within the factory provides a consistent product that lasts with less home maintenance and repairs than a stick built home. For example, if a homeowner has a leaky roof and can't get the builder to fix it. The recourse is different between a stick build and a factory built home. The stick built home warranty process is with the builder, if the homeowner is not satisfied with warranty results the only other step is the legal court system and a complaint to the state licensing bureau. The manufactured home warranty process starts with the dealer, if the homeowner is not satisfied with warranty results the next step is the home's manufacturer, state HUD code agency, HUD ombudsman, state consumer affairs manufactured home division, state manufactured housing institute, and the state manufactured home industry group (Grissim 2003). All the prior opportunities are available prior to any legal action taken by the homeowner. The manufactured home warranties generally exceed a stick built home with fewer complaints.

\section{REAL ESTATE INVESTMENT}

Why invest in real estate with manufactured homes? The market! There will continue to be a market for manufactured homes because of the cost and quality. Ten years ago, half of many real estate agent sales were first 
time home buyers. Today the costs of homes in many areas like California are so high that only $10 \%$ of the buyers are first time buyers. In 2004 the number of first time home buyers nationwide dropped to 26\% (Florkowski 2005). Fannie Mae, the largest source of financing for mortgages, predicts a critical shortage of affordable housing in this decade. Fannie Mae has recently introduced a 5\% down 30 year fixed rate mortgages for manufactured homes. Wells Fargo and Countrywide Home Loans both finance manufactured homes and site-built homes with financing that closely mirrors the regular mortgage market (Sullivan 2005). Many investors will be moving to manufactured home investments because of one name "Warren Buffet".

Berkshire Hathaway Investment Company controlled by Warren Buffet has entered the manufactured housing market with the purchase of Clayton Homes. The competitor, Fleetwood, had its stock surge by 12.8 percent after the Clayton Homes deal was announced and many other manufactured home competitors stock rallied as well (Katzanek 2003). Clayton has since added more manufacturers like Karsten Homes and most recently the retail division of Fleetwood Homes to become one of the largest manufactured home builders in the United States (Shikes 2005). Multibillionaire Warren Buffet does not move into a market that he hasn't intensely researched. He can see that manufactured housing is going to be one of the biggest industries for first time buyers and retirees. There is both a market demand for families trying to purchase their first home and for all the baby boomers that are going to be retiring. Those retirees will either be downsizing to smaller homes, adding a second home, or both. Retirees are flocking to manufactured housing communities for the minimal maintenance, single story mobility, better security, small town feeling, and attractive prices (Correa 2002).

Noticing the continued interest in the new manufactured homes, we chose to do a preliminary experiment to see the interest of consumers visiting a large Southern California Home and Garden Show.

\section{INTERESTED MARKET}

We performed an exploratory study to see if our presence at a Southern California Home and Garden Show that was displaying seven manufactured home models would influence traffic to a new website. The first day of the show 500 business cards were setout. The cards were of high quality with full color front bleed and printed on both sides. The cards were chosen over flyers as to not get mixed up with the pile of flyers thrown together. Many venders throughout the show push flyers into the hands of all the passing individuals. They cause an overwhelming amount of flyers that the consumer has to sort through. Many won't take the time to sort through the flyers and end up throwing them all away when they arrive home. The business card is small enough to place into a purse, pocket, or wallet to be easily stored. The solid color helps the card stand out from traditional business cards. Green was used as to symbolize money, savings, and home. The front of the card provided the "Company Name" with text reading "Plan on purchasing a manufactured home? Buy wholesale and save thousands!" then the website address was provided followed by the manufacturers represented. The back of the card was white and listed information such as "\#1 Wholesale dealer in Southern California, Manufactured and Modular Homes, Wholesale Prices, Investment Seminars". The only contact information provided on the card was the website address, there were no email or phone numbers. Additional contact information was provided on the website including email, phone, and fax numbers.

The cards were placed in plastic business card holders on the California Manufactured Home Institute table which was located at the east entrance of the manufactured home displays. The cards were not monitored as to how soon they were gone. The original 500 cards generated 293 hits to the website over the first week.

The second week we returned with 500 more business cards. These cards were distributed personally to manufactured home viewers as they toured the manufactured homes that day. The following week 312 hits were generated to our website. Those 312 hits provided a $6 \%$ increase in website visits from the previous week. This number did not take into consideration participants from the first week that may have reentered the site or visited for the first time nor does it consider the people who may visit the website in the future.

From the 1000 cards that were distributed at the Home and Garden Show, 605 website hits were recorded. That is a $61 \%$ return rate on website hits to the number of business cards distributed at the Home and Garden Show. 
The number of website hits was not significantly increased by the personal distribution of the website business cards. It didn't matter if sales personnel were physically present when distributing the web address business cards.

\section{MANAGERIAL IMPLICATIONS}

Perception, the cards were quality and provided professionalism without pressure. Consumers were able to select the cards without any sales pressure or obligation. That cuts down on waste by non market consumers gaining cards. Personally handing out the cards to the consumers could provide pressure and sales personnel inconsistency. The numerous sales personnel distributing the cards provide a different perception with each salesperson. The used car salesman mentality is a factor of consumer attitudes toward manufactured homes. That attitude could have been a factor in why personal representation did not significantly increase the return rate of website hits.

Consumer attention could be gained more successfully with carefully designed advertising materials than with a group of sales personnel. Managers need to be aware of how their sales personnel are perceived by the consumers at the specific location. The trade show goals and costs should be carefully looked at. Partnering/sharing a table with a complementary product where information can be displayed and distributed may be a more financially strategic decision.

\section{FUTURE RESEARCH}

Future research could compare the solicited and unsolicited distribution of advertising pieces, by comparing the number of advertising pieces distributed and time frame in which the consumers respond. Other factors such as the number of responses, home sales, and new distributors would also be analyzed.

An additional future study would be to measure consumer perception of manufactured homes. A survey instrument would be tied to a drawing to win an outdoor BBQ Island. Home and Garden Show participants can pickup a form to judge each of the manufactured homes with one manufactured home being the winner. At the beginning of the form they will fill out attitudinal questions on Manufactured Housing along with demographic and psychographic data. At the end of their home evaluation form will be another set of attitudinal scales on manufactured homes. The before and after results can be tested for significance of attitude change after the participant evaluated the manufactured homes.

\section{CONCLUSION}

The manufactured home industry has had a problem with perception for many years. With the involvement of Warren Buffet the manufactured home industry is about to start a new era. The quality is now surpassing many stick built homes and the financing is also following. Real estate agents are gaining more interest in the manufactured housing market because of the demand by real estate consumers. Real estate investors are migrating into the manufactured home market because of the quality construction, availability, consumer demand, and excellent returns on investment with very little risk. With the increased quality and acceptance as real estate, the manufactured homes market will continue to grow.

This paper looked at the changing industry of manufactured housing. The manufactured housing market has been joked about for many years and exploited during major storms. The industry has listened to those perceptions and is now building homes of equal and better quality than stick built homes. Manufactured homes are the future for first time home buyers and for the retiring baby boomers. The perception of manufactured homes is changing with a much better product and a little more respect. The industry has a long way to go when it comes to perception but with the help of Warren Buffet maybe the market will finally be a little better understood. 


\section{REFERENCES}

1. Burnside, Kevin (2002) Buying a manufactured home: How to get the most bang for you buck in today's housing market Cycle Publishing, San Francisco pg 1-168

2. Correa, Barbara (2002) Going mobile; Whether they are priced out or biding their time, many home buyers are turning to manufactured homes or apartments Daily News, Los Angeles, Oct 20, 2002, pgB1

3. Florkowski, Joe (2005) First-time homebuyers rarer The Sun, August 27, 2005, pgB1

4. Graves, Sheri (2004) Building a bend new look; Manufactured houses are replacing mobile homes in increasingly pricey California housing market The Press Democrat, Santa Rosa CA, May 1, 2004, pgR1

5. Grissim, John (2003) The complete buyer's guide to manufactured homes and land: How to find an reputable dealer and negotiate a fair price on the best kept secret in American housing Rainshadow Publications, Sequim WA, pg1-235

6. Handley, John (2005) Can systems-built houses withhold tornadoes? Knight Ridder Tribune Business News, Washington: April 24, 2005, pg1

7. Harris, Roger (2004) Manufactured homes an affordable option; Gain popularity in California Chicago Tribune, Illinois, Jan 11, 2004, pg7

8. Hullibarger, Steve (2001) Developing with manufactured homes, Manufactured Housing Institute, Arlington, VA

9. Katzanek, Jack (2003) Buffet buy lifts housing industry; Fleetwood shares soar after Berkshire Hathaway purchases rival Clayton The Press Enterprise, Riverside CA, April 3, 2003, pg E1

10. Koestner, Mark (2005) Sahara Homes exec looks back on the manufactured homes market Knight Ridder Tribune Business News, Washington: August 10, 2005, pg1

11. LePage, Andrew (2004) Fab prefab manufactured homes get new look The Sacramento Bee, Sacramento, CA, Sept 1, 2004, pgD1

12. Long, Thayer (2004) Finding loans for rural customers: Getting to know the section 502 program Modern Homes, March-April 2004, pg 24-25

13. Manufacture Home Institute Understanding today's manufactured homes www.manufacturedhousing.org

14. McClintock, Jamie (2003) More Californians turn to manufactured homes Chicago Tribune [West Final Edition]: Illinois, April 26, 2003, pg26

15. Navarro, Mireya (2005) Trailer trash? Not a scent of it New York Times, New York, Apr 10, 2005 pg9.6

16. Shikes, Jonathan (2005) Look who's buying in: Warren Buffet could alter fortunes of inland industries Press Enterprise, August 4, 2005, pgE1

17. Skipitares, Connie (2005) A mobile home park that doesn't look like one Knight Ridder Tribune Business News, Washington: April 8, 2005, pg1

18. Sullivan, T.J. (2005) Assembly required: As factory-built housing takes new shapes, they're attracting diverse buyers caught in the housing crunch Los Angeles Times, Los Angeles, CA, Jun 12, 2005, pgK1

19. Taylor, Steven (2004) Manufacture homes the buyers guide: How to realize your dream in a manufactured home Cycle Publishing, San Francisco pg 1-144

20. United State Census (2004) www.census.gov 